\title{
Próba dialektycznego spojrzenia na pomiar przedsiębiorczości w organizacjach
}

https://doi.org/10.33141/po.2005.10.01

Mariusz Bratnicki

\section{Przedsiębiorczość organizacyjna: istota, wymogi i wymiary}

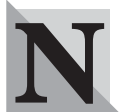

ie wdając się w szczegółowe rozważania dotyczące definiowania przedsiębiorczości (Bratnicki, 2002) przyjmuję w ślad za Sharma i Chrisman (1999), że pojęcie to obejmuje akty tworzenia organizacyjnego, odnowy, innowacji, pojawiające się w obrębie istniejącej organizacji lub niezależnie od jakichkolwiek związków z nią. W procesie przedsiębiorczości następuje przekształcenie idei w żywotny biznes, a konkretniej uruchomienie nowych przedsięwzięć w sposób proaktywny i przezwyciężajacy ryzyko, nie ociagając się z tworzeniem i wykorzystywaniem szans (Barringer i Ireland, 2006). Proces ten nie jest trywialny ani też przypadkowy (Birch, 1987) i w odniesieniu do już istniejących organizacji jest nazywany przedsiębiorczością organizacyjna, ze strategicznego punktu widzenia, gdzie chodzi głównie o tworzenie i utrzymywanie przewagi konkurencyjnej (Hitt, Ireland i Hoskisson, 2005). Przedsiębiorczość poprzez odkrywanie i wykorzystywanie szans tworzy przestrzeń dla zarządzania strategicznego i dotyczy rozwoju, tworzenia nowych wartości dla klienta, a w ślad za tym tworzenia bogactwa dla właścicieli czy też przedsiębiorców. Oznacza to spełnienie wymogów w zakresie (Ireland, Hitt i Sirmon, 2003):

- wykształcenia przedsiębiorczego nastawienia umysłu powodującego czujność organizacji i jej uczestników wobec szans, jak również potencjału generowania renty kreowanego przez niepewnośc;

- uformowania kultury organizacyjnej, w której są oczekiwane nowe idee i twórczość, występują zachęty do podejmowania ryzyka, tolerowane jest niepowodzenie, promowane jest uczenie się, cenione są innowacje, a zmiana jest traktowana jako przesłanka powodzenia;

- strategicznego zarządzania zasobami - strukturalizacji portfela zasobowego, łączenia zasobów w związki tak, aby powstały produktywne zdolności (np. w zakresie badań i rozwoju) podwyższania umiejętności organizacji w celu tworzenia wartości dla klientów i bogactwa dla udziałowców;

- wykorzystywania zdolności i kompetencji organizacji do tworzenia innowacji produktowych, rynkowych, procesowych w celu realizacji strategii działalności.

Pojęcie przedsiębiorczości organizacyjnej robi karierę z powodu pozytywnego wpływu na efektywność
Przegląd Organizacji, Nr 10 (789), 2005, ss. 8-12 www.przegladorganizacji.pl Towarzystwo Naukowe Organizacji i Kierownictwa (TNOiK) organizacyjną zarówno finansową, jak i pozafinansową (Zahra, Jennings i Kuratko, 1999). Działalność przedsiębiorcza jest ważna dla efektywności organizacji, bez względu na ich wielkość i to zarówno w gospodarkach transformujących się, jak i w gospodarkach rozwiniętych (Antoncic i Hisrich, 2003). Wpływ ten jest zarówno bezpośredni, jak i pośredni, czyli z mediacją wsparcia organizacyjnego znajdujacego wyraz w zaangażowaniu kadry zarządzającej, przygotowaniu ludzi do odkrywania szans, w doborze i wynagradzaniu ludzi, w likwidowaniu barier biurokratycznych, czy też w dostępności zasobów łącznie z czasem. Nic zatem dziwnego w tym, że przedsiębiorczość organizacyjna, oznaczajaca proaktywna, odważna działalność innowacyjna i formowanie nowych organizacji, podwyższa poziom efektywności organizacyjnej. Wyniki badań empirycznych wykazują tė̇, że rezultaty przedsiębiorczości organizacyjnej rozpatrywane przez pryzmat efektywności organizacji rosną po kilku latach (Wiklund, 1999).

Równocześnie narasta porozumienie co do trzech wymiarów tego procesu: $\bullet$ innowacyjności odnoszącej sie do zaangażowania $\mathrm{w}$ tworzenie nowych produktów, dóbr, usług oraz nowych modeli biznesowych, które opisują, w jaki sposób organizacja projektuje i przeprowadza wymiany ekonomiczne poprzez granice oraz w jaki sposób wiąże zasoby i rynki produktowe w poszukiwaniu tworzenia bogactwa, $\bullet$ odważania się (venturing), czyli tworzenia nowych biznesów dla istniejących albo nowych rynków, rozwijania nowych kompetencji i zdolności organizacji, utrzymywania organizacji w stanie czujności wobec szans, $\bullet$ odnowy strategicznej odzwierciedlającej różnorodne aktywności zmierzające do ożywienia działalności organizacji, do zbudowania nowych umiejętności konkurencyjnych, czy do zmiany ciagu strategicznego w fundamentalny sposób - a więc przeobrażający zasadniczo bazę technologiczna, rewidujący systemy i procesy, stawiajacy wyzwania wobec dotychczasowych założeń o rynku i o konkurencji (Zahra, 2005).

Rdzeniem przedsiębiorczości organizacyjnej jest proces odkrywania i wykorzystywania szans (Shane i Venkataraman, 2000), co jest typem zachowań znamionujących te organizacje, które budują swą przewagę konkurencyjną tworząc i przetwarzając nową wiedzę (Katila, 2002) tak, aby proaktywnie konkurować na krawędzi chaosu i czasu (Eisenhardt, Brown i Neck, 2000) przekształcając wiedzę w szanse, a te $\mathrm{z}$ kolei w nowe wartości i bogactwo. Rdzeniem przed- 
siębiorczości organizacyjnej, podobnie jak zarządzania strategicznego, jest tworzenie bogactwa (Ireland, Hitt, Camp i Sexton, 2001), ale z punktu widzenia przedsiębiorczego nastawienia umysłu (McGrath i MacMillan, 2000) i przedsiębiorczej inteligencji wspomaganej - w znacznej mierze - przez zdolność organizacji do uczenia się i oduczania (Hitt i Reed, 2000). Konkretniej mówiąc i posługując się koncepcją dominującej logiki (Bettis i Prahald, 1995), można wskazać na cykl organizacyjnego uczenia od strategii konkurencyjnej do wzmacniania zachowania, gdzie rolę ogniw pośredniczących pełnią wartości wraz z oczekiwaniami oraz miary efektywności.

\section{W dialektycznym polu sit: główne komponenty i logika pomiaru przedsiębiorczości}

W

dalszych rozważaniach przyjmuję dwa założenia. Po pierwsze, na poziomie całej organizacji kluczowe znaczenie ma konfiguracja struktur wzmacniających oraz konfiguracja struktur ograniczajacych poczynania uczestników (Bratnicki, 1978). Pomiędzy tymi konfiguracjami zachodzi sprzeczność charakterystyczna dla przeciwieństw chaosu i ładu. Po drugie, pomiar przedsiębiorczości organizacyjnej powinien w swej logice uwzględniać dialektyczną dynamikę tego procesu. Oznacza to, że konkretne miary powinny tworzyć układ odzwierciedlający godzenie kluczowych sprzeczności. Krótko mówiąc, proponuję sposób mierzenia oparty na dialektycznej dynamice pola sił.

Skrzyżowanie poziomów oraz nośników z wymiarami przedsiębiorczości tworzy macierz pomiaru, gdzie w każdym z dwunastu pól mamy do czynienia ze specyficzną sprzecznością (tabela). Dialektyczna natura przedsiębiorczości, podobnie jak każdej nowej koncepcyjnej czy też społecznej konfiguracji, ma swój wyraz ontologiczny, epistemologiczny, relacyjny, praktyczny i estetyczny. Podążając tym tokiem myślenia (Bhaskar, 1993), warto zastanowić się, w jaki sposób współczesne organizacje budują swoją przedsiębiorczość na ontologicznym poziomie tworzenia swej przyszłości, na epistemologicznym poziomie twórczego odkrywania szans, na relacyjnym poziomie interesariuszy i mobilizowania zasobów, na praktycznym poziomie przypisywania estetycznej jakości działaniom oraz interakcjom. Wielopoziomowość dialektycznej konfiguracji ma

Tab. Główne obszary pomiaru przedsiębiorczości organizacyjnej

\begin{tabular}{|c|c|c|c|}
\hline \multirow[b]{2}{*}{ Poziomy i nośniki } & \multicolumn{3}{|c|}{ Wymiary przedsiębiorczości } \\
\hline & $\begin{array}{c}\text { Innowacyjność, } \\
\text { wprowadzanie } \\
\text { znaczących nowości }\end{array}$ & $\begin{array}{c}\text { Odwaga, stawianie czoła } \\
\text { wymaganiom, zapuszcza- } \\
\text { nie się w nieznane }\end{array}$ & $\begin{array}{c}\text { Proaktywność, } \\
\text { dokonywanie dużych } \\
\text { zmian }\end{array}$ \\
\hline $\begin{array}{l}\text { Ontologiczny } \\
\text { i epistemologiczny } \\
\text { Strategiczne nastawianie } \\
\text { umysłu na szanse i na wyko- } \\
\text { rzystywanie niepewności }\end{array}$ & $\begin{array}{c}\text { Swoboda manewru } \\
\text { przedsiębiorczego } \\
\text { Rozmyślne kontra } \\
\text { wyłaniające się tworzenie } \\
\text { i kształtowanie szans }\end{array}$ & $\begin{array}{l}\text { Przedsiębiorcze rozwiązy- } \\
\text { wanie problemów budowa- } \\
\text { nia kompetencji } \\
\text { Analiza i logika kontra } \\
\text { intuicja i twórczość } \\
\text { w radzeniu sobie } \\
\text { z nieokreślonością }\end{array}$ & $\begin{array}{c}\text { Inwestowanie w przedsię- } \\
\text { biorczy rozwój organizacji } \\
\\
\text { Inwestowanie w kapitał } \\
\text { materialny kontra } \\
\text { inwestowanie w kapitał } \\
\text { intelektualny jako nośnik } \\
\text { wartości firmy }\end{array}$ \\
\hline $\begin{array}{l}\text { Relacyjny } \\
\text { Formowanie kultury organiza- } \\
\text { cyjnej przez przedsiebbiorcze } \\
\text { przywództwo mobilizujące } \\
\text { interesariuszy }\end{array}$ & $\begin{array}{c}\text { Odpowiedzialność za } \\
\text { przedsiębiorcze inicjatywy } \\
\text { Odgórne kontra oddolne } \\
\text { identyfikowanie i interpre- } \\
\text { towanie szans w czasie } \\
\text { mobilizowania zasobów } \\
\text { i legitymizacji }\end{array}$ & $\begin{array}{l}\text { Przedsiębiorcze tworzenie } \\
\text { bogactwa } \\
\text { Efektywność ekonomiczna } \\
\text { kontra odpowiedzialność } \\
\text { społeczna }\end{array}$ & $\begin{array}{l}\text { Zaangażowanie w działal- } \\
\text { ność przedsiębiorczą } \\
\text { Motywacja zewnętrzna, } \\
\text { rywalizacja ekonomiczna } \\
\text { kontra motywacja } \\
\text { wewnętrzna, współpraca } \\
\text { społeczna }\end{array}$ \\
\hline $\begin{array}{l}\text { Praktyczny } \\
\text { Przedsiębiorcze zarządzanie } \\
\text { zasobami, zdolnościami, } \\
\text { kompetencjami organizacji }\end{array}$ & $\begin{array}{c}\text { Architektura organizacyj- } \\
\text { nych czynników sprzyjają- } \\
\text { cych postępowaniu w ślad } \\
\text { za szansami } \\
\text { Ścisłe powiązanie kontra } \\
\text { luźne powiązanie elemen- } \\
\text { tów organizacji }\end{array}$ & $\begin{array}{c}\text { Żywotność } \\
\text { przedsiębiorczości } \\
\text { Technokratyczny kontra } \\
\text { humanistyczny projekt } \\
\text { organizacji }\end{array}$ & $\begin{array}{l}\text { Złożoność interakcji } \\
\text { komunikacyjnych } \\
\text { Dokładność kontra szyb- } \\
\text { kość przepływu informacji } \\
\text { w czasie wykonywania } \\
\text { zadań }\end{array}$ \\
\hline $\begin{array}{l}\text { Estetyczny } \\
\text { Zachowania przedsiębiorcze } \\
\text { tworzące nową wartość } \\
\text { i bogactwo }\end{array}$ & $\begin{array}{c}\text { Społeczna elastyczność } \\
\text { Trwałość kontra niepokój } \\
\text { zachowań organizacyjnych } \\
\text { dla zapewnienia wrażliwo- } \\
\text { ści na niespodzianki, braki } \\
\text { i bariery }\end{array}$ & \begin{tabular}{|c} 
Społeczna dynamika \\
przedsiębiorczości \\
Zmiany rewolucyjne kontra \\
zmiany ewolucyjne
\end{tabular} & $\begin{array}{l}\text { Rozmieszczenie zasobów } \\
\text { dla przedsiębiorczego } \\
\text { wykonawstwa } \\
\text { Jednorazowe, pełne } \\
\text { zaangażowanie zasobów } \\
\text { kontra stopniowe zaangażo- } \\
\text { wanie zasobów }\end{array}$ \\
\hline
\end{tabular}


wyraźne odniesienie do czterech wymogów przedsiębiorczości (Ireland, Hitt i Sirmon, 2003) i do czterech procesów przedsiębiorczości (Bratnicki, 2004). I tak, dwa pierwsze poziomy (ontologiczny i epistemologiczny) wiążą się z nastawieniem umysłu i procesem przedsiębiorczości strategicznej. Poziom relacyjny koresponduje z kulturą organizacyjną i przywództwem przedsiębiorczym. Poziom praktyczny ma swoje odniesienie w zasobach, zdolnościach, kompetencjach i zarządzaniu przedsiębiorczym. W końcu, na poziomie estetycznym centralną rolę odgrywają tworzenie względnie trwałej przewagi konkurencyjnej i zachowanie przedsiębiorcze.

Dość powszechnie wiadomo, że dobra perspektywa analityczna nie jest substytutem wszechstronnego spojrzenia na przedsiębiorczość, które obejmuje wzajemnie powiązane sprzężenia przede wszystkim tworzące złożoność całego procesu (Davidsson, 2003; Low, 2001). Jak powiada Cook (2001) organizacja posiadająca całościowy kontekst jest pełna interaktywnych związków pomiędzy myśleniem, planowaniem i działaniem, które są kształtowane przez sieć sprzężeń zwrotnych zarówno dodatnich, jak i ujemnych. W tym nurcie mieści się też wielopoziomowa struktura nośna ułatwiająca zrozumienie motywacji i zachowań ludzi w organizacjach (Hultman i Gellerman, 2002). Według tej koncepcji każdy z czterech poziomów - osobisty, interpersonalny, zespołowy, organizacyjny - zawiera w sobie pętlę o identycznej sekwencji procesów. Konkretyzując, uświadamianie potrzeb i pragnień w powiązaniu z myśleniem (ocena faktów, przeświadczenia o sobie i innych osobach, przeświadczenia o otaczającej rzeczywistości) ukierunkowuja wartościowanie i decydowanie, a to z kolei przewodzi działaniom (zachowaniom). Uważam, że pełnokontekstowa organizacja i wielopoziomowa struktura nośna działań organizacyjnych są zintegrowane z trzema procesami przedsiębiorczości (Zahra, 2005). Już wyjaśniam w czym rzecz. Myślenie jest rdzeniem innowacyjności. Planowanie oparte na wartościowaniu i na decyzjach stanowi kręgosłup odważania się. Działanie jest kluczem do proaktywności. Tak oto doszliśmy do istoty przedsiębiorczości organizacyjnej, gdzie uwzględniłem kompleksowość, wielopoziomowość i wielowymiarowość tego procesu.

Strategicznie rzecz biorąc, składniki przedsiębiorczości organizacyjnej powinny być silnie powiązane. Jak bowiem podkreśla się, organizacja, posiadając dużą liczbę elementów pozytywnie wzajemnie wpływających na siebie, tworzy złożoność trudną do naśladowania przez konkurentów i przez to mogącą być źródłem przewagi konkurencyjnej (Rivkin i Siggelkow, 2003). Dlatego też, jeżeli sprzeczności przedsiębiorczości organizacyjnej zostana zespolone, to posiadane przez organizację zasoby, zdolności i kompetencje mogą być użyte do podwyższenia efektywności przedsiębiorczego funkcjonowania i rozwoju. Co więcej, według teorii współewolucji (Levin i Volberda, 1999), samoorganizacja i spontaniczne wyłanianie się nowej konfiguracji przedsiębiorczości organizacyjnej (nowego ładu) powstaje z interakcji pojedynczych nośników i wymiarów. Oto przyczyna, dla której przedsiębiorczość organizacyjna staje się dysfunkcjonalna, o ile nie jest kształtowana całościowo. Wszystko to zaś ma służyć innowacyjności, odważaniu się i proaktywności organizacji.

Punktem wyjścia do dalszych rozważań jest moje silne przekonanie, że w każdym z dwunastu pól macierzy pomiaru przedsiębiorczości organizacyjnej występuje zasadnicza sprzeczność i wynikające zeń wyzwanie polegające na zespoleniu tworzacych ją przeciwieństw. Ogólnie mówiąc, stan pogodzonych sprzeczności jest celem idealnym jako forma organizacji, gdzie równocześnie sprzyja się szansom (chaosowi jako przesłance rozwoju) i działaniu (ładowi jako przesłance przetrwania). Nie wdając się zbytnio w szczegóły, mam w tym przypadku na myśli organizację: • przezorną strategicznie i dokonująca inteligentnych eksperymentów, $\bullet$ mobilizującą społeczność uczestników i interesariuszy do formułowania i realizowania wizji, - w której ludzie partnersko improwizują, a całość jest wrażliwa na niespodzianki i braki, • budowana wokół samoorganizacji i samoodnowy, przy odpowiednim tempie i zakresie dokonywanych zmian.

\section{Profil przedsiębiorczości organizacyjnej}

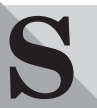

zukając przesłanek powodzenia współczesnej organizacji trudno nie docenić wiarygodnego wyróżniania się dzięki swym zachowaniom, które są powiązane z modelem biznesu i znajdują odzwierciedlenie w filozofii zarządzania, wizji i misji danej organizacji; w wewnętrznym zaangażowaniu uczestników organizacji w symbolicznych przekazach dla interesariuszy; w organizacyjnej architekturze sprzyjającej nietypowym zachowaniom podejmowanym przez ludzi z własnej inicjatywy (Bacon i Pugh, 2003). Zatem całościowy pomiar efektywności organizacyjnej powinien uwzględniać wartości, postawy, kompetencje, dostrzeżenia ludzi. Kłopot w tym, że nie wszystkie aspekty efektywności organizacji dadzą się zmierzyć na podstawie obiektywnych danych. Dlatego też czasami jesteśmy uzależnieni od psychometrycznych (subiektywnych czy też miękkich) danych, takich jak opinie czy też percepcje. Wprawdzie w literaturze dotyczącej zarządzania strategicznego (Dess i Robinson, 1984; Powell, 1996) nawoływano do wykorzystywania miar percepcyjnych czy miar subiektywnych, ale przypadki stosowania tego zalecenia sa niezmiernie rzadkie. Moja propozycja pomiaru przedsiębiorczości uwzględnia powyższe sugestie i zawiera zestaw jakościowych mierników, które stanowią dopełnienie wskaźników obiektywnych.

Bazując na przedstawionym wywodzie zakładam, że jakościowy pomiar efektywności przedsiębiorczości organizacyjnej dotyczy kontekstu organizacyjnego sprzyjającego zachowaniom przedsiębiorczym, którego podłoże tkwi w decyzjach dotyczących godzenia kluczowych sprzeczności przedsiębiorczości organizacyjnej. Sugerowane przeze mnie narzędzie diagnostyczne zwane profilem przedsiębiorczości organizacyjnej ma pomóc kadrze zarządzającej w określeniu atutów i słabości organizacyjnych uwarunkowań tego procesu. Tworzenie kwestionariusza diagnostycznego oparto na koncepcji dialektycznej dynamiki przedsiębiorczości, przedstawionej w tabeli, która modyfikuje przedsiębiorcze procesy, podobnie jak mowa daje znaczenie językowi. Narzędzie pomiaru zawiera dwana- 
ście pytań dotyczących poszczególnych sprzeczności. Pytania w kwestionariuszu zostały tak skonstruowane, że osoba posługując się siedmiostopniową skalą oceny dokonuje dwóch wyborów charakterystycznych dla danej sprzeczności (np. efektywność ekonomiczna i odpowiedzialność społeczna).

Uzyskane wyniki ocen nanosi się na siatkę profilu przedsiębiorczości opartą na osiach współrzędnych (rysunek). Na osiach odłożone są wartości skali ocen od 1 do 7. Profil przedsiębiorczości występujący w danej sprzeczności obliczany jest jako odległość od prawego górnego rogu siatki (punkt o współrzędnych (7; 7)) do punktu o współrzędnych odpowiadających ocenie respondenta (punkt o współrzędnych (x; y)). Profil ten liczy się więc następująco:

$$
d=\sqrt{(7-x)^{2}+(7-y)^{2}}
$$

Im wyliczona odległość jest większa, tym mniejsza jest efektywność organizacji w zespalaniu badanej sprzeczności i tym samym przedsiębiorczość występująca w sprzeczności. Zatem punkt o współrzędnych $(7 ; 7)$ odzwierciedla stan idealny (profil przedsiębiorczości $=0)$, a punkt o współrzędnych $(1 ; 1)$ - wynik najgorszy.

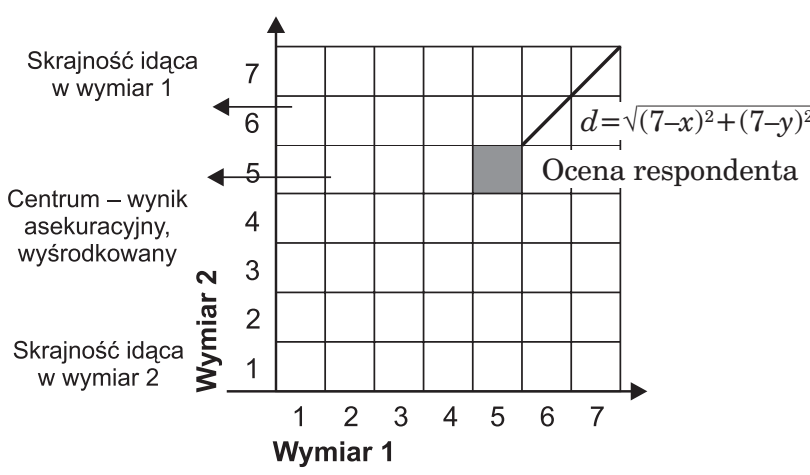

\section{Rys. Siatka profilu przedsiębiorczości organi- zacyjnej}

Przechodząc do metodyki pomiaru należy stwierdzić, że poleganie na jednym informatorze $\mathrm{z}$ danej organizacji wiąże się $\mathrm{z}$ istotnymi ograniczeniami poznawczymi wynikajacymi z posiadanych przez niego ukrytych teorii działania (Gerhard, Wright, McMahan i Snell, 2000; Podsakoff, MacKenzie, Lee i Podsakoff, 2003). Wiadomo również, że podstawy wiedzy i umiejętności poznawcze zespołu zarządzającego znajduja wyraźne odzwierciedlenie w funkcjonowaniu i rozwoju organizacji (Hambrick i Mason, 1984). W szczególności charakterystyki (wraz z procesami) zespołu zarządzającego wpływaja na przedsiębiorczość w dziedzinie tworzenia nowych produktów (Srivastava i Lee, 2005), w aspekcie rozpoczynania nowych rodzajów działalności (Talaulicar, Grundei i Werder, 2005), a niektórzy definiują orientację przedsiębiorczą organizacji w kategoriach skłonności zarzadzajacych nia do innowacyjności, podejmowania ryzyka i proaktywności (Morris i Paul, 1987). Patrząc szerzej, znajduje- my się na gruncie klimatu organizacyjnego obejmującego kolektywne postawy i przekonania uczestników organizacji odnoszące się do sposobów wykonywania zadań (Ashkanasy, Wilderom i Peterson, 2000). Tak rozumiany klimat organizacyjny stanowi odbicie wbudowanych weń strategicznych wartości i przekonań, wiążących się z pożądanym funkcjonowaniem organizacji i priorytetami, a kształtowanych przez przywództwo (Bratnicki, 1986; Schein, 1985).

Wszystko to podkreśla znaczącą rolę władzy w kształtowaniu percepcji organizacyjnego kontekstu przedsiębiorczości. Stąd też moja propozycja, aby jako źródła informacji wykorzystać osoby tworzące dominującą koalicję, zgodnie z odwzorowaniem konfiguracji władzy według procedury sprawdzonej w moich poczynaniach konsultingowych (Bratnicki, 1992). Ta metodyczna sugestia nie tylko pozwala zmniejszyć mankamenty korzystania $\mathrm{z}$ indywidualnych źródeł informacji, ale pozwala również powiązać pomiar przedsiębiorczości organizacyjnej z aktualnym ładem korporacyjnym. Pozostaje jednak problem strategicznego porozumienia odnośnie do organizacyjnego kontekstu przedsiębiorczości, które można osiągnać poprzez dyskusję i zespołowe uczenie się w czasie specjalnej sesji oceniającej, realizowanej według logiki aktywnego doskonalenia zarządzania (Bratnicki, 1993).

\section{Zakończenie}

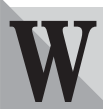
konsekwencji zastosowania scharakteryzowanego podejścia odpowiedź na pytanie dotyczące poziomu efektywności przedsiębiorczości organizacyjnej nie jest wprawdzie precyzyjna, ale daje istotne przesłanki do podjęcia rzetelnej i otwartej dyskusji nad dalszym ożywianiem mierzonego procesu. Co więcej, zaprezentowane narzędzie ma zastosowanie w całej gamie organizacji - małych i dużych, lokalnych i globalnych, młodych i starych. Jednakże nie traktuję go jako zamkniętej sprawy, ponieważ mam świadomość potrzeby prowadzenia dalszych prac poświęconych zarówno treści sprzeczności przedsiębiorczości organizacyjnej, jak i sposobów dokonywania pomiaru efektywności.

W tym świetle nabierają znaczenia zagadnienia przywództwa menedżerskiego, zespalania ewolucji z rewolucyjnymi przeobrażeniami, strategicznego definiowania domeny działalności, kreowania zintegrowania strategii ze strukturą organizacyjną i systemami działania, bilansowania współpracy majacej swe podłoże we wspólnie podzielanych wartościach z rywalizacją mającą korzenie polityczne, przezwyciężania nietolerancji i inercji wynikajaccej z dotychczasowych sukcesów, kształtowania samoorganizacji umożliwiającej spontaniczność, wykorzystywania władzy organizacyjnej do wzmocnienia organizacyjnego uczenia się, stawiania ambitnych celów, utrzymywania konsekwencji w działaniach i w decyzjach, budowy zaufania jako podpory efektywności komunikowania się, uformowania nowej kultury organizacyjnej przy równoczesnym zachowaniu zaangażowania i lojalności pracowników charakterystycznych dla pierwotnej kultury, aktywizowania zmiany strategicznej poprzez zdobywanie i wykorzystywania władzy organizacyjnej. 
Lista problemów formowania przedsiębiorczości wydaje się nie mieć granic.

prof. dr hab. Mariusz Bratnicki Akademia Ekonomiczna im. Karola Adamieckiego w Katowicach

\section{BIBLIOGRAFIA}

[1] ANTONCIC B., HISRICH R.D., 2003, Privatization, Corporate Entrepreneurship and Performance: Testing a Normative Model, „Journal of Developmental Entrepreneurship", 8, s. 197-218.

[2] ASHKANASY N., WILDEROM C.P.M., PETERSON M.F., (red.) 2000, Handbook of Organizational Culture \& Climate, Thousand Oaks, Sage.

[3] BACON T.R., PUGH D.G., 2003, Winning Behavior: What the Smartest, Most Successful Companies Do Differen$t l y$, New York, AMACOM.

[4] BARRINGER B.R., IRELAND R.D., 2006, Entrepreneurship. Successfully Launching New Ventures, New Jersey, Pearson Prentice Hall.

[5] BETTIS R.A., PRAHALD C.K., 1995, The Dominant Logic: Retrospective and Extension, „Strategic Management Journal", 16, s. 5-14.

[6] BHASKAR R., 1993, Dialectics: The Puls of Freedom, London/New York, Verso.

[7] BIRCH D., 1987, Job Creation in America, New York, Free Press.

[8] BRATNICKI M., 1978, Force-field Analysis in Research on Decision-making Processes, Berlin, IIM.

[9] BRATNICKI M., 1986, Kultura i przywództwo: społeczne tworzenie rzeczywistości $w$ organizacji gospodarczej, „Organizacja i Kierowanie", 1, s. 169-188.

[10] BRATNICKI M., 1992, Wtadza organizacyjna, przywództwo menedżerskie i zmiana strategiczna, Ruda Śląska, Krajowe Wydawnictwo Gospodarcze.

[11] BRATNICKI M., 1993,Doskonalenie procesu zarzadzania $w$ przedsiębiorstwie. Podejście zintegrowane, Katowice, WAE.

[12] BRATNICKI M., 2002, Przedsiębiorczość i przedsiębiorcy wspótczesnych organizacji, Katowice, AE w Katowicach. [13] BRATNICKI M., 2004, Organizational Entrepreneurshipscape: Contradictions, Processes, Dimensions, Forms and Questions, Dabrowa Górnicza, Academy of Business.

[14] COOK W.J., 2001, The Art and Science of Holistic Strategy, Westport, Quorum.

[15] DAVIDSSON P., 2003, The Domain of Entrepreneurship Research: Some Suggestions, [w:] Advances in Entrepreneurship, Firm Emergence and Growth, vol. 6, praca zbiorowa pod red. J.A. KATZ i D.A. SHEPHERDA, Oxford, Elsevier Science Ltd., s. 315-372.

[16] DESS G.G., ROBINSON R.B., 1984, Measuring Organizational Performance in the Absence of Objective Measures: The Case of the Privately-held Firm and Conglomerate Business Unit, „Strategic Management Journal”, 5, s. 265273.

[17] EISENHARDT K.M., BROWN S.L., NECK H.M., 2000, Competing on the Entrepreneurial Edge, [w:] Entrepreneurship as Strategy: Competing on the Entrepreneurial Edge, praca zbiorowa pod red. G.A. MEYER i K.A. HEPPARD, Thousand Oaks, Sage, s. 49-62.

[18] GERHART B., WRIGHT P.M., McMAHAN G.C., SNELL S.A., 2000, Measurement Error in Research on Human Resources Decisions and Firm Performance: How Much Error is There and How Does it Influence Effect Size Estimates?, „Personnel Psychology”, 53, s. 803-834.

[19] HAMBRICK D., MASON P., 1984, Upper Echelons: The Organization as a Reflection of Its Top Managers, „Academy of Management Review", 9, s. 192-206.

[20] HITT M.A., REED T.S., 2000, Entrepreneurship in New Competitive Landscape, [w:] Entrepreneurship as Strategy:
Competing on the Entrepreneurial Edge, praca zbiorowa pod red. G.A. MEYER i K.A. HEPPARD, Thousand Oaks, Sage, s. $23-45$.

[21] HITT M.A., IRELAND R.D., HOSKISSON R.E., 2005, Strategic Management: Competitiveness and Globalization, Cincinnati, South - Western Publishing.

[22] HULTMAN K., GELLERMAN B., 2002, Balancing Individual and Organizational Values. Walking the Tightrope to Success, San Francisco, Jossey-Bass.

[23] IRELAND D.R., HITT M.A., CAMP S.M., SEXTON D.L., 2001, Integrating Entrepreneurship and Strategic Management Actions to Create Firm Wealth, „Academy of Management Executive", 15(1), s. 49-63.

[24] IRELAND R.D., HITT M.A., SIRMON D.G., 2003, A Model of Strategic Entrepreneurship: The Construct and Its Dimensions, „Journal of Management”, 29, s. 963-989. [25] KATILA R., 2002, New Product Search Over Time: Past Ideas in Their Prime?, „Academy of Management Journal”, 45 , s. $995-1010$.

[26] LEVIN A.Y., VOLBERDA H.W., 1999, Prolegomena on Coevolution: A Framework for Research on Strategy and New Organizational Forms, „Organization Science”, 10, s. 519-535. [27] LOW M.B., 2001, The Adolescence of Entrepreneurship Research: Specification of Purpose, „Entrepreneurship Theory \& Practice", 25, s. 17-25.

[28] McGRATH R.G., MacMILLAN I., 2000, The Entrepreneurial Mindset, Boston, Harvard Business School Press. [29] MORRIS M.H., PAUL G.W., 1987, The Relationship Between Entrepreneurship and Marketing in Established Firms, „Journal of Business Venturing”, 2, s. 247-259.

[30] PODSAKOFF P.M., MacKENZIE S.B., LEE J.Y., PODSAKOFF N.P., 2003, Common Method Biases in Behavioral Research: A Critical Review of Literature and Recommended Remedies, „Journal of Applied Psychology”, 88, s. 879903.

[31] POWELL T.C., 1996, How Much Does Industry Matter? An Alternative Empirical Test, „Strategic Management Journal", 17, s. 323-334.

[32] RIVKIN J., SIGGELKOW N., 2003, Balancing Search and Stability: Interdependencies Among Elements of Organizational Design, „Management Science”, 49, s. 290-311. [33] SCHEIN E.H., 1985, Organizational Culture and Leadership, San Francisco, Jossey-Bass Publishers.

[34] SHANE S., VENKATARAMAN S., 2000, The Promise of Entrepreneurship As a Field of Research, „Academy of Management Review", 25, s. 217-226.

[35] SHARMA P., CHRISMAN J.Y., 1999, Toward a Reconciliation of the Definitional Issues in the Field of Corporate Entrepreneurship, „Entrepreneurship Theory \& Practice”, 23(3), s. 11-27.

[36] SRIVASTAVA A., LEE H., 2005, Predicting Order of New Product Moves: The Role of Top Management in Corporate Entrepreneurship, „Journal of Business Venturing”, 20, s. $459-481$.

[37] TALAULICAR T., GRUNDEI J., WERDER A., 2005, Strategic Decision Making in Start-ups: The Effect of Top Management Team Organization on Processes on Speed and Comprehensiveness, „Journal of Business Venturing”, 20, s. $519-541$.

[38] WIKLUND J., 1999, The Sustainability of Entrepreneurial Orientation - Performance Relationship, „Entrepreneurship Theory \& Practice", 24, s. 37-48.

[39] ZAHRA S.A., JENNINGS D., KURATKO D., 1999, The Antecedents and Consequences of Firm Level Entrepreneurship: The State of the Field, „Entrepreneurship Theory \& Practice", 24, s. 45-65.

[40] ZAHRA S.A., 2005, Corporate Entrepreneurship, [w:] The Blackwell Encyclopedia of Management, vol. III, Entrepreneurship (2 wyd.), praca zbiorowa pod red. M.A. HITTA i R.D. IRELANDA, Malden/ Oxford/Carlton, Blackwell Publishing, s. $42-45$. 